\title{
With the Faltering Liberal Journalism Model; Is China Set to Lead Emmerging Powers in Shaping New Global Journalism?
}

Kwizela Aristide Basebya*

Department of Communication Studies, Communication University of China, Chaoyang Qu, Beijing Shi, China

\begin{abstract}
Whereas the US President Donald Trump names American Media and their journalistic practices fake news and enemy of the people hence complement the long scholarly claims that the American Liberal Journalism is in crisis and unfriendly on social-economic development initiatives and to the global south, "China's journalism model" which put particular emphasize on social-economic development with government intervention is now gaining grounds. While some scholars see the 'Going Global' of Chinese media a high time for the Chinese model to be globalized others reserve contentious.

This article highlights the readiness of Chinese media and journalism practices in affecting local media and journalism practices across the World in reflecting to the U.S's liberal journalism model. It reviews various scholarly suggested journalism models in China such as 'positive reporting', 'developmental journalism' and 'Soviet-Communist model' but argues that while these values are now exported globally, there is no clear and consistent model due to what articulate China's domestic media and journalism environment is unpredictable depending on the political and economic circumstances and regulations are prone to party-state interventions. Through thoroughly reading various publications by researchers and scholars from both China and the Western perspectives, reading official documents and adhering to direct commentaries or directives from Chinese top officials and academicians on media and journalism practices; this article have concluded that due to political system dissimilarities among emerging global powers there should be a new approach of joining and mobilizing other developing countries and especially the emerging BRICS powers in developing a clear and consistent media and journalism model since majority of the world countries are already caught in a trap of liberal democracy and journalism regardless the impasse the model bleeds especially in social-economic development.
\end{abstract}

Keywords: Faltering; Liberal; Journalism; USA; China; Global; Order; Shaping

\section{Introduction}

From President Obama's "New era of Global Engagement" and "Shared Global Responsibilities" to President Trump's "America First", "America Interests in Global Responsibilities" and erosion of America's long standing "Shared and global imposed values" such us "democratic governance" and "Press Freedom", it is apparent that there is an alarm for a new global power to shape the new world order [1].

Indeed; as the long standing global order hawker, the US seems to loosen its powers as witnessed by both the Obama and now Trump's administration. However, for media and journalism practices, this is just the cementing of the long in crisis U.S championed values such of media and journalism values as it has been labeled a "Crisis Journalism" since it is increasingly lack the courage to stand up the government and government propaganda. Or in some cases it is even failing to report the truth and concentrating communication powers to few elites due to media monopolies and personal interests.

Consequently; during his inauguration speech, President Trump evidenced the hesitancy in pushing some of the long standing globalized American values and commitments by stating clearly that "He is not here to represent the world rather to represent America" and he has started to erode the long globally imposed media practices of "media as fourth estate of the government" and "Media as government watchdog" by labeling all the critical media to his administration as "Fake News" and "Enemy of American People".

All these incidents signify that; the US is now slackening on the long standing democratic values especially values related to the freedom of the press, journalism integrity and the essence of media as the fourth estate of the government.
However, to have a new global order whether through embracing the existing global orders, reforming or replace with new ones will need either of the following key factors; Firstly; a unilateral government or global power with values' supremacy enough to export to other countries and make them adorable and part of their daily practices.

Secondly; will need a multilateral approach whereby nations and or multinational organizations may take the floor to form certain new values and globalize them. But by relying on historical facts as ${ }^{1}$ Patrick articulates; this will depend on China's readiness since China is the second world economic superpower to the USA it is therefore the global power closely monitored as the future global shaper.

Nevertheless; to understand China's readiness to shoulder and shape the new global journalism it is very important to understand how the current in predicament Anglo American journalism model was organized and become widely accepted as universal model. This will therefore give the base of highlighting China's media and journalism

${ }^{1}$ This was the brief paper originally presented at a conference on Leadership and the Global Governance Agenda, November $10-11,2009$, China Institutes of Contemporary International Relations (CICIR) Beijing, PRC.

${ }^{*}$ Corresponding author: Kwizela Aristide Basebya, Department of Communication Studies, Communication University of China, Chaoyang Qu, Beijing Shi, China, Tel: +8613121273177; E-mail: arisreality@gmail.com, kwizela_aris@yahoo.co.uk

Received November 21, 2017; Accepted April 19, 2018; Published April 23, 2018

Citation: Basebya KA (2018) With the Faltering Liberal Journalism Model; Is China Set to Lead Emmerging Powers in Shaping New Global Journalism?. J Mass Communicat Journalism 8: 367. doi: 10.4172/2165-7912.1000367

Copyright: (c) 2018 Basebya KA. This is an open-access article distributed under the terms of the Creative Commons Attribution License, which permits unrestricted use, distribution, and reproduction in any medium, provided the original author and source are credited. 
practices and the approach undertaken by Beijing in globalizing Chinese media and journalism.

This article focuses on Beijing and Washington as the two economic giants carry different approach on media and journalism values. While the Liberal Journalism model (Anglo-American journalism model) is globally widely spread but with a 'crisis face' within the U.S. as revealed by various scholars such as ${ }^{2}$ Bagdikian and being criticized by developing countries for biases, negativities and not friendly to developmental approach, the Chinese media and journalism model which focuses on positive portrayals, state complacency, political ideology preservism and social-economic development backed with social-economic development achievements in China has gained much attention by scholars. While some Scholars disagree with China's media and journalism model due liberalism syndrome, others see the model as an alternative to the current in crisis Anglo-American and liberal model. However, the question of how the model is globalized and applied by other developing nations and be the new global media and journalism model remains unanswered.

Indeed; whereas Ward [2] also admits that the current journalism is in crisis and acknowledges that there has been scholarly efforts to reshape it; he nevertheless argue that the reshaping has paid insufficient attention to a major trends: the impact of the globalization of journalism and the rising new theoretical and practical approaches towards reshaping global journalism as exemplified by China.

Therefore; this article aims at highlighting the readiness of China to export its media and journalism practices enough to affect local media and journalism practices. Also; it clearly shows the strategies used by the U.S versus those seems to be undertaken by China and later come up with the best practice for China to export its media and journalism practices across the world and make them part and parcel of the global media practices hence new global journalism model.

\section{Reflection on the Methodologies}

The article thoroughly and randomly passed more than 68 publications by researchers and scholars from both China and the Western perspectives. It purposively feature, official documents and adhering to direct directives from Chinese top officials such President $\mathrm{Xi}$ Jinping and former President $\mathrm{Hu}$ Jintao on 'Going Global' of Chinese Media. However Chinese Academicians' commentaries regarding globalization of Chinese media and their practices are both intensively and extensively accommodated. Based on these literary discussions this article have come up with unfathomable analysis which will add to the current discussion on Chinese media and journalism globalization (Go Out) and later help to shape the growing sense of demand of new global media and journalism model which some scholars especially from China and developing countries have long been echoing for new approach to global media and journalism values especially after the failure of the first attempt by UNESCO and the Global South in 1980's at the Conference on the "New World Information and Communication Order" (NWICO).

${ }^{2}$ Bagdikian documents the consolidation of most of the mass news, entertainment, and publishing media in the USA under the "Big Five" conglomerates: Time Warner, Disney, Rupert Murdoch's News Corporation, Viacom, and Bertelsmann. In his two books he argues that American Media and journalism is in crisis. There has been extensive distortion both at a fine grain (de facto corporate advertising for specific products presented to the public as news and editorial commentary) and at a coarse grain (broad right-wing, pro-business bias across the board).

\section{The Evolution of the current Media and Journalism values}

There are various theories regarding the origin and globalizing of the current Anglo-American (Liberal) journalism model. While various scholars haven't clearly established the evolution of it; scholars such as Stephens in the $16^{\text {th }}$ century demonstrate that journalism was invented in the week Venetalian gazettes of the second half of the $16^{\text {th }}$ Century (Mitchell Stephens: 156-7) in Venus.

On the contrary, Ward argues that identifying an exact point at which journalism and its values begins is as hopeless a task. "In the early modern period, there is no "first work" of print journalism. Nor is there an official date when a group of practitioners began to call themselves "journalists" and carried out activities clearly distinct from the work of printers, publishers, pamphlet writers, or ballad composers.

However, in his project of developing new history of journalism course at the Calicut University, India, ${ }^{3}$ Padmanabhan reveals that; journalism has many documented history regarding its evolution. $\mathrm{He}$ demonstrates that the first newspaper named Peking Gazette started in China in 618 due to discover of papers and it was hand written and distributed to readers and other newspapers such as File (Germany in 1609) and the already mentioned Gazette (Venice, 1600's) followed [3].

Coherently; both Padmanabhan [3] and Chalaby [4] acknowledge that most of these early newspapers could not survive for long because rulers were not happy with them as some of them started criticizing their rule. Also they were not journalistic in nature and they had no clear model and format of journalism.

Padmanabhan [3] points newspapers such as 'The Weekly News' (UK, 1655), 'Public Occurrences' (US, 1690), 'The Boston Newsletter' (US, 1704), Pennsylvania Evening Post (1783) and The New York Times (1851) as the early newspapers with permanence face.

Indeed Chalaby [4] argues that journalism is an invention of $19^{\text {th }}$ Century as during this period is when progressively the journalistic discourse became a distinctive class of text and the journalistic field developed its own discursive norms and values such as objectivity and neutrality.

Articulately; Ward, Padmanabhan, [3] and Chalaby [4] agree in common that; the evolution of journalism and journalists started with the establishment of these early newspapers in the United Kingdom and United States.

Both Chalaby [4] and Ward [2] reiterate that; journalism is not only an invention of $19^{\text {th }}$ Century it is also an Anglo-American invention. "It is in the United States and to be lesser degree in England that the discursive practices and strategies which characterized journalism were invented" [4]. The growing of press, enlightenments and public sphere especially in England, France, and the United States made journalists to claim for tribunes of the public, protecting their liberty against government. They advocated reform and eventually revolution. "By the end of $19^{\text {th }}$ Century, the press was a socially recognized institution, a power to be praised or feared, with guarantees of freedom in the postrevolution constitutions of the United States and France".

Indeed, Chalaby [4] and Ward [2] reveal that the Anglo-American

Dr.N.PADMANABHAN is an Associate Professor P.G. at the University of Calicut, India, School of distance education. This was his project in developing a bachelor English program in Journalism. He have described in details history of journalism in various global perspectives. His work can be traced through http://www. universityofcalicut.info/SDE/EngIVHistoryofJournalism.pdf 
model invented journalism values and ethical considerations such as 'Free from political partisanship', 'fourth estate of the government as watchdog player' 'interviewing', 'News Reporting,' 'Objectivity', 'Accuracy', 'Neutrality', 'Complete, 'Proximity', 'editorial independence' and so forth were then adapted by other countries such as France and later be part of the global journalism practices.

However; the question of how these Anglo-American global media and journalism practices and values became globalized while their inventions were meant to serve the Anglo-America social-political setting becomes a debate which many scholars such as Chabby [4], Ward [2], Caminit [5], Gagliardone et al. [1], Matos [6] come with different conjectures.

Chabby [4] argues that by creating modern conception of news and developing journalistic practices the American and the British achieved a unique discursive revolution. He adds that; their discursive journalism practices were neither literary as it was in France whereby poets dominated journalism industry nor political.

"In the United States and in British the press and journalistic practices grew independently from the literary and political ideological fields.....due to multiparty democracies or bi-partism, journalists could claim to be 'neutral' of politics while the market forces that forced for advertising and sales be the main sources of revenues made journalism to develop differently because market forces played a more important role in the development of the American and British press and journalism values" [4].

Indeed; as Chabby [4] points political neutrality hence realization of separation between government and the press (Fourth estate of the Government), other scholars such as Caminit [5] affirm that; this sense of 'media as fourth estate' and 'media as revenue generator' played a major role in globalizing American journalism and traditional media practices as it pressed for press de-regulation and integration in the 'governance system' and "elimination of many traditional, institutional and legal barriers to cross border transactions"

Therefore while Matos [6] and Caminit [5] see the elimination of these domestic traditional, institutional and legal barriers together with communication technological advances such as satellite and cable television and the growing use of internet as the reason for easy penetration of Anglo-American media and journalism values across the globe; they all agree that this has also resulted to declining of National Broadcasts and state owned media and local journalistic practices and hence dominance of a 'single global media model' in 1990s which he labels it as the Liberal American Model.

"The main features of this growing convergence towards the liberal American Model are weakening of government intervention and decline of the role of the state in communications, with the move towards market regulation, commercialization and the predominance of Anglo American journalistic professionalism, accompanied by the crisis of the public service broadcasting and print media tradition" [6].

However; sending journalists/reporters abroad, establishing media bureaus and the fact that local media due to economic and technological constraints are ending up consume online and by then telegraph sent stories; Chabby [4] argues that these has hugely contributed to smooth assertion of Anglo American and liberal American media and journalism model as local media and journalists picked these news already in an Anglo-American model.

Chabby [4], Reagan et al. [7], Wasserman et al. [8] add the issue of linguistic internalization by all agreeing that English is a predominant language of education and research in the academic world. "It can easily condense other languages hence a decisive advantage in journalism and indeed many have favored the emergence of distinct mode of writing in Anglo America media and journalistic values".

English is the predominant language as Reagan et al. [8] have noted: "Nowhere is the influence, power and dominance of English more clear than in the academic world...... as a language of international communication English increasingly dominates academic and scientific publishing, discourse and even instruction".

Wasserman et al. [8] believe scholars from non-English speaking backgrounds have inadequate opportunities for publishing their research. Nonetheless Matos [6], Caminiti [5] all affirms the issue of political and decision powers enough to affect and make other states follow as the major key towards exporting and localizing values. For example Patrick argues that the American policy of exceptionalismin in both political culture and its global affection has made the globalization and standardizing of its media and journalism values globally.

This as it has been argued earlier has made American liberal media values and practices an integral part of governance to majority of the states in the World. And it has been the alliance push between America and its counterparts in Global North while the United Nations with its global governance organs have considered them as part of the good governance score measurement and developmental agenda. ${ }^{4}$ (UNDP, 2008).

To be sure as Breit et al. [9] argue, this Anglo-American journalism model and globalised paradigm has affected tertiary education systems, resulting in "local" cultural knowledge and Indigenous ways of knowing being disregarded or abandoned in preference for the Western ideals.

\section{American Liberal Democracy and Journalism Universalism}

While one can observe the issue of globalization of American liberal or Anglo American journalism model in the aspect of professionalism practices and globalization aspect, the global supremacy of capitalism ideology after the slither of the socialist and communism values with the cold war anxieties and later the rise of liberal democracies as already revealed to incorporate media and journalism in governance, made this 'single global media and journalism model' a trouble free realization. As Hafez [10] put it, the end of the Cold War plus the technological developments in the media sector, satellite television and the internet, seem to have changed everything.

Wei [11] affirm this as they argue that when ideologies spread from powerful nations they legitimate themselves by promoting beliefs and values that are congenial to them, naturalizing and universalizing such beliefs so that they have become 'self-evident and apparently inevitable. "The subordinate nations are left without option to accept the ideology... they lose their consciousness of combating the ruling class and regard the current social relations as natural and inevitable" [11].

Conversely, Caminiti [5] argues that is not only the "soft power"

${ }^{4}$ This work includes support to electoral processes but it does not stop once the elections are over. It also involves continued support to parliaments and decentralized local governance to enhance the checks and balances that allow democracy to thrive; promoting human rights, the rule of law and access to justice by helping to strengthen the impartiality and effectiveness of national human rights machinery and judicial systems; ensuring freedom of expression and access to information by strengthening legislation, media capacities, and e-governance; promoting women's political empowerment; and integrating anti-corruption measures throughout. 
approach that reduced the bare bones of exporting and localizing American Liberal democracy and journalism values across the globe. He argues that soft power must be supported by 'hard' political and economic power despite the massive movement of media flows and values across continents, cultures and communities.

Definitely; as Patrick affirms; substituting certain solid values and practices within states and blocks historically has been among of the vexing challenges in World politics as he point the struggle during the cold war as the U.S. and its allies was involving in both hard and soft powers in making sure that the former USSR and its socialist allies and values across the World collapses.

Indeed, many scholars such as Caminiti [5], Gagliardore et al. [1], Matos [6] despite of their great theoretical and academic contributions in revealing the integration of western media values and journalistic practices in democratic governance; they together affirms that; the liberal democracy has tremendous impact on the current wider acceptance of Anglo-American media and journalism model. As Lee [12] affirms, the extension of the press and Anglo-American journalism has historically been an extension of democratic participation. "The empowerment of audience as members of the public community is a key to any democratic media practice" [12].

Yet economists and development scholars across the World [13-15] though with disagreements have shown how the US and its North allies are increasingly using their economic and political muscles as leverage to impose liberal democracies across the World and apply tough measures such as isolation, trouble bans, sanctions, aid withdrawals, aid and grants strings and so forth to developing countries and even the giants that seems to violate the principles of "America liberal democracy" and "Liberal Press" that follows strictly the Anglo-American model.

Indeed, according to Berggruen, this is the ongoing move of the US and its allies of the G7 and he speculate for a new order to be welcomed and integrated there must be a clear and acute competition over dominance.

However; despite of the global wide spread of the Anglo-American/ liberal journalism model as Chalaby [4] argues, many researchers remain unaware of this influence because its export is much less visible than the export of actual movies and television series. "As a result journalism has been widely accepted as a universal discursive form" [4].

On the other hand; Breit [9] argue that this predominance of Anglo-American and Eurocentric approaches to journalism has broad implications. It affects what is taught, what is seen as quality journalism, and how journalism ethics are framed. Furthermore, it has implications for the kind of research that is conducted and seen as valid....." The quality of journalism practice and research is evaluated in terms of how far along they have developed towards some Western ideal. This often entails a framework of "talking back" to the West rather than being fully located or understood in the place of origin" [9].

Moreover; Ojo [16], Hafez [10], Ward [2] reveal the consequences of globalizing The Anglo-American (Liberal) journalism model. They all point issues such as treating less developed countries news as not deemed news worth unless is during wars, crisis or violence. Also the problem of focusing mostly on political news rather than economic, cultural or cultural development seems be of less paramount.

The Western journalism model has not deviated from its distortion of news and "use of the pejorative adjectives and stereotypes" [16] and indeed today it share the biases and limitations of the liberalism upon which it is based. It is grounded in enlightenment forms of thought that are male, Euro-centric, individualistic, and universal [2].

\section{China's Traditional Media, Journalism and Global Outreach}

While the U.S. led media and journalism is now increasingly termed as "crisis" and 'fake news' where it is based, this globally spread model is looked as unfriendly when comes to social development, focus on negativities and with developing countries it is a model which has widely discussed as a biased with consistent agenda of negating local and cultural values and not friendly to social-economic development initiatives. Therefore; the world need an optional eye towards shaping new journalism.

Indeed since almost all the scholars agree that; economic and political muscles play major role in media and journalism values' export and internationalization; therefore the next optional eye is China as the second largest economy behind the U.S and with political and journalism system that hugely differ from that of the U.S. but with tremendous social-economic successes.

However; the questions that set alarms in today's scholastic are: Are the domestic Chinese traditional media and journalistic practices and values making universal impact given the western ones widespread? Is 'the going out' by Chinese media resulting to a new model of global journalism?

This part briefly highlights various literatures from China media and journalism history, current circumstances and the 'going out' strategy as part of the substitution measurement of current traditional media and journalism practices and values. The main goal is to establish facts if there is a move for new global media and journalism order or model.

Though there are many theories regarding the evolution of Chinese media and journalism values [1,12,17-19] use different approaches in analyzing the dynamics of Chinese media and journalism practices. But one thing in common all the analysis recognizes the internal social-political dynamics within China as the core approach. External influences seems to be less paramount as all the scholars seems to agree that haven't altered much compare to the internal social-political dynamics.

Indeed; being a power house with media and journalism evolved much from its internal socio-political configurations and have a command system; it is not a bombshell that some scholars such as Wekesa and Yanqiu have termed China's traditional media and journalism practices as unique and other scholars reiterate the need to be exported to other countries (especially developing countries) backed with the ideological and social-economic successes at home.

For example; Wang [20] argues that "If a country has an admirable culture and ideological system, other countries will tend to follow it". Affirmatively; being the pioneer of 'Going Out' by Chinese Media and Journalism practices; the former Chinese president $\mathrm{Hu}$ Jintao emphasize that "the enhancement of China's international status and international influence must be reflected both in hard power including the economy, science and technology and national defense power and in soft power such as culture and media."

However; Lee [12] analyses the uniqueness of Chinese media and journalism practices that is now making global appearances through 'Going Global' and "Soft Power Expansion" strategy.

According to Lee's [12] three models that greatly align with the historical analysis by majority of Chinese and western scholars as 
partly mentioned earlier are Confucianism, Maoism, and Communist capitalism.

"The Confucian model treats the audience as a target of education, guidance, and enlightenment; the Maoist model, a target of mobilization and indoctrination; and the Communist-capitalist model, a target of ideological conformity and exploitation for profit" [12].

Lee [12] shows clearly that the Confucianism, Maoism models were predominantly in the Chinese press and journalism during the prereform era while the other of Communist-capitalist which insists on ideology preservation and profit maximization evolved after the reform era especially with the effect of social-market economy in early 1980s.

To be sure; while market economy seems to sweep Chinese traditional media and journalism in a direction of commercialization with the "state subsidies" being chopped off as Hu articulates, currently the issue of preserving domestic ideology and political discourse that was shaken in late 1980s after internal party's ideological contradictions play major role.

For example; when President Xi Jinping took over as the Party's general secretary in 2013 there was a new emphasis on ideology... and he called for journalists to take the initiative to lead opinion in the politically correct direction and make contributions to the achievement of the "Chinese Dream".

Consequently; as Yan [21] and Zhao [19] argue that in this sense media is completely dominated by the Chinese Communist Party as its mouthpiece for disseminating CCP's ideology, Lee [12] concludes that the boundaries between journalists and the party are arbitrary, in flux, and not at all rules-based." The purpose is to "force the public to comply with government policy' and serves as the 'propagator' and 'promoter' of the policy" $[22,23]$.

Indeed; in upholding this, official directive by President Xi Jinping in February 2017 shows clearly that Chinese media must follow the part line, uphold the correct guidance of public opinion and promote 'Positive propaganda' as the main theme. "Chinese state media must tell China's story to the world better and become internationally influential".

Yet the 'Going Out' by Chinese traditional media and journalism practices seems to carry this party line approach as Keane argues their primary role is to counter Western media as there is a huge sense among powerful elites and academics that China needs to counter negative reporting from the West, often foreign journalists and also a political mission especially of spreading The Communist Party ideology and propaganda in a compulsory job of accelerating its domestic and international legitimacy.

In fact, Yang [21] affirms that; while many major western media face budget cuts, Chinese media (with the same domestic face) are busily expanding offices and recruiting staff: Xinhua News Agency currently has over 180 news bureaus globally, publishing news text, photographs, audio/video programs around the clock in eight languages. China Central Television (CCTV/Global CGTN) has over 70 foreign bureaus, broadcasting to 171 countries and regions in six UN official languages. China Radio International, the world's second biggest radio station after the BBC, broadcasts in 64 languages from 32 foreign bureaus, reaching 90 radio stations worldwide. Other official Chinese media including China Daily, People's Daily, Global Times are all stepping up their efforts.

Nonetheless; 'going out' by Chinese media and journalists is a political mission as it is hugely funded by the part-state system in Beijing under China's "Soft Power Expansion". For example; building and establishing Confucius Institutes across the globe in an extraordinary move to globalize Chinese language and Culture is also going hand in hand with China's traditional media and journalism expansion.

According to an official Chinese government website, there are now 500 "Confucius Institutes" around the world - with the aim of 1,000 by 2020 . In 2015 , their budget was $\$ 310$ million, and from 2006-2015 China spent $\$ 1.85$ billion on Confucius Institutes.

$\mathrm{Xu}$ Lin, the Director-General of the Confucius Institute headquarters, known as 'Han ban', says to the Huffington post that "our work is an important part of our soft power. We want to expand Chinese language and culture's influence" Xu Lin, however the question on how, when and to what extent in compare to English internationalization remains unanswered.

As English take center stage to majority of countries enough to be integrated to local curriculums, dominate the academic sphere and simplify the penetration of Anglo-American journalism model across the globe; the extent to which Chinese language has gone far academically and resourcefully to back up the Chinese journalism model remains imprecise.

\section{Is China a new 'Global Journalism Shaper?'}

For certain values and practices to be normalized and 'glolocalized', there must be tremendous global adaptations, incorporation and standardizations in the daily routines. Indeed; even; the affection of traditional media and journalism values and practices beyond the border of their origin as it has been witnessed from the US point of view, cannot evade this reality.

According to Sun, for the traditional media and journalism values to be effective they have to influence other nations' own affinity, normative values, media, business practices, education and language. He also adds the issue of sharing values, beliefs and sentiments with local media as the major element of affection.

Accordingly, ${ }^{5} \mathrm{Gagliardone}$ et al. [1] make clear the issue of attracting audience and readers for both electronic and print media respectively. They argue that; it is not just about media presence and flowing rather understands how media attracts public attention as Herman emphasize; enough to construct international agenda that influence national governments.

Nonetheless; creating attention and setting news agenda comes from the journalistic point of view that; content of the media such as news should observe proximity, exclusivity and timeliness. The same as Sun explains; issues such as media credibility (how they tell story and what kind of story?) and audience perception against other media plays a major role.

However; while Chinese media seems to 'Go Global' at the time Western media with their journalism practices are dominating the playground with majority of developing countries seems to fall under the liberal journalism model; for China to establish a new global media and journalism order will not depend on negotiating with Western powers rather creating affinity and affection especially to developing countries by institutionalizing the process.

${ }^{5}$ Report based on the outcomes of the workshop organized by the program in Comparative Media Law and Policy (PCMLP) at the University of Oxford and the Stanhope Centre for Communications policy research. The workshop reflected on China's growing influence in Africa's communications sector and on the implications this has on the prevailing local western approaches to media assistance and media development in Africa and beyond. 
This is from the fact that the 'Going Out' by Chinese traditional media and their journalistic practices meet with an incompatible media and journalism practices plus social-political organization across the World.

Indeed; Jiang et al. [24] affirm this by revealing that; public sentiments and opinions together with the assertive advocacy, media and civil society groups (All set and funded by Western powers) make China media practices and traditional diplomacy increasingly difficult. "Chinese media have yet to address many challenges in adapting to the unique developing countries media market"

It is real that while China as Weissmann [11] argues put particular emphasize on its own experiences of modernization as a successful late developing country being a possible model for others in all aspect, these prevailing incompatibilities as Xiaojuan indentify them from competitive politics to democratic values such as separation of powers, freedom of press with the insistence of private press and active civil societies need to be sort out as how the West managed to break through and make influence on local policies, laws and regulations. Although there are state backed efforts in melting the above dilemma such as journalism exchanges, offering scholarships to journalists, short and long term trainings, joint ventures with local media houses and so forth Jiang et al. [24], points issues such as biased approach of China by only targeting state owned media and journalists and leave behind those from private media and few number of scholarships in the media and communication sector as obstacles towards breakthrough. They also reveal that little is known about the impact of China's capacity building on individual journalists.

Indeed with the presence of these trained personnel in developing countries and the current Chinese media internationalization process the prospects would be more audience attraction by Chinese media and the realization of the Chinese media practices and values. However, Gagliardore et al. [1] reveal that the question of attracting audiences in a wake of western media influences and an increasingly competitive market for loyalties remain unclear.

However; in attracting 'glocal audience' the issue of news proximity and timeliness must be kept into consideration. As many scholars have stipulated; people tend to read or watch news or programs that touches their lives most.

On the contrary, Jiang [24], Gagliardore et al. [1] all in their literary works; see the dilemma in Chinese media's ways of covering and reporting stories.

While Jiang [24] point the sense of 'positive reporting' in expense of negative incidents something affects Chinese media credibility Sun highlights the issue of 'no go zone' by Chinese media and journalists when formulating and covering stories and Gagliardore et al. [1] show how Chinese media have been criticized for focusing only on 'image building' of China and leave behind stories such corruption and lack of transparency in contracting as well as Chinese nationals' involvement in environment crime like poaching and illegal lodging among others in many parts of the world and more seriously Africa. According to Sun these stories that seem to be a 'No Go Zone' by Chinese media attract Western media and to be specific local media where Chinese media and journalists are operating.

Cautiously some scholars find difficulties in differentiating the nature of stories Chinese media cover and those covered by their western counterparts. For example during the Beijing Summit of the Forum on China-Africa Cooperation (FOCAC) in 2006 media was identified as joint tool in counteracting the western biases against both Africa and China but Vivien Mars in her research of comparing CCTVAfrica (now CGTN) with BBC on Africa representation she concluded that "It remains questionable whether CCTV/CGTN's Africa coverage rivals that of the $\mathrm{BBC}$ in terms of breadth of portrayal and visual vividness"

Indeed; while Chinese government have prioritized media in building bilateral ties and define common goals with developing countries; scholars have criticized the lack of clarity and coherence of Chinese media and journalism model when partnering. Also others such as Jiang [24] have raised serious concern of why there is no strategy to establish an alternative journalism model to the western news agenda as all developing countries as it is for case of China fall under the same trap of negative portrayals and misrepresentation.

Scholars such as Gagliardore et al. [1] have discussed various models exemplified by Chinese journalism practices although none of the model seems to be consistent and single focused to be standardized and be adapted and glolocalized [24].

Whereas Shubo and Ronning relate Chinese journalism to libertarian model or "half free" style on the one hand on the other hand, they point out that Chinese media "is used instrumentally" and therefore fall into the Soviet-Communist model (citing Schramm 1956).

However; Wekesa reviews both official documents and secondary literature to conclude that "the traits of the Chinese media model include focus on stories that showcase China as peace-loving; emphasis on commonality of China and other developing countries (Africa); accentuating mutual benefits and win-win principles; focus on cultural exchanges; and China as a development role model. He named the model as "Positive Journalism Model" similar to Gagliardore et al. [1] who also stipulate 'developmental journalism model.'

Consequently, according to Gagliardore et al. [1] the lack of clear and consistent mode of journalism in China is caused by China's domestic media and journalism environment whereby it is unpredictable depending on the political and economic circumstances and as unknown underlines due to party-state system, regulations that are issued by the government through the state council are always prone to party interventions so are not enduring.

Nonetheless; Ward [2] argues that; to develop a journalism model and the need to export and localize to other countries need first to explore both common ground and differences between countries.

Indeed; while Ward [2] and Gagliardone et al. [1] reveal that Africa and China share the commonalities such as communitarianism as Africa have ubuntu (respect for community) and China has harmonious society (and the still workable collectivism), Wekesa and Yanqiu argues that Chinese state-party is rolling out a developing world media alliance against the West. "In fact this anti-West theme is not a secret from the China end of things and indeed from some African, Asia and Latin America countries as many have openly complained in much the same terms".

Nevertheless, it is not just the solidarity of sharing socialcommunistic organizations and 'sicknesses' of 'negative representation' to Western media that seems to be articulated as the possible option for a new global journalism model to challenge the liberal journalism from the West; rather China's multilateral engagements with other emerging powerful nations under the BRICS (Brazil, Russia, India, China and South Africa) promise to transform World order although scholars such as Patrick et al. [25] question their political unevenness and insist 
that China as the powerful nation within BRICS, hasn't yet influenced a formulation of a clear role as a global power and the commitments this may entail.

Alternatively; while pushing Chinese traditional media and journalistic values is highly tied with adulation of The Communist Party's ideology and China's social-economic development as part of inspiring and be adorable by other developing countries; the question of how far Chinese politics and economic success model has impacted the rest of the world enough 'to be sentinel' remain indistinct.

Gagliardore et al. [1] give an example of Africa; they reveal that despite of years of unprecedented Sino-Africa engagement and the vocalized developmental model, the affection and aspirations of Chinese political model remains uncertain and insignificant just as for now.

Therefore; as the US plays the policy of 'China Containment' and 'China's Engagement' it is evident that while economic wise China have directly impacted the global economy; politically and to be specific ideologically; China seems to swim alone. And as Caminit [5] argue; since media and journalistic values affection need political and decision powers, media alone are not power holders but they constitute by and large the space where power is decided.

\section{Discussion and Conclusion}

Though China as a second global superpower has managed to evade the crisis of the state media and its journalism practices despite the US and its allies pressure as witnessing through the booming of the state run media with expansion around the globe, China as the 'eyed super power' has the role to export its own media and journalistic values, organization and professional doings enough to impact the World. The reasons are clear; as it has been revealed, China carries both unique political and media system backed with enormous social-economic development.

Furthermore the current 'Single Global Media and Journalism model' have prolonged criticisms and distrusts by the developing countries include China for its biasness and negative portrayals and it is now looked as predicament where it is originating.

Therefore; China with a domestic successful journalism model seem to be caught in a single choice between either readjusting to the same in crisis liberal journalism model or push for its own media and political values to the rest of the World as the Western traditional media and political values as revealed throughout this article are widely spread and integrated to majority of global nations and regional groupings despite of global abhorrence.

Nonetheless, China's adaption to this liberal American journalism model means to be forced to reform its political system in order to align with pluralized politics. As Guoming argue; China's media and journalism adhering to western journalism values such as openness, transparency and objectivity is impossible in the absence of an opposition style of politics.

Indeed; Patrick [26] insist that the US wants a gradual transition from one party system rule to political pluralism in China so that to immerse political pluralism where as China seeks continued CCP rule and envisions China's emergence as the key player on framing new international order. In this circumstance it is obvious China need to push its media and journalistic values globally without political reform which seems not to be an agenda as for now.
Therefore; contrary to the US which when was pushing for the current in crisis 'Single Global media and journalism model' enjoyed strong alliances and support from other global powers as they share the same pluralized political systems, China seems to stand with few shoulders with fellow global emerging powers such as the BRICS as shown to the findings part seems to be already trapped on the Western political and media values except Russia which stands as hybridist.

On the other hand the issue of 'Global English language affection' to the current Anglo-American journalism is another issue which China needs to hold on [27-30]. While English as revealed later by Chobby is a global language with 'journalistic uniqueness', Chinese language remains widely applied in Chinese domestic media and even for Chinese media to go global they have to compel to English language.

This not only affect China's expansion of its media and journalistic practices as it lacks domestic backed theoretical literatures to the international arena, according to various personal discussion with some Chinese scholars this is also a setback to Chinese scholars and academicians who find it difficult to push globally some theoretical frameworks regarding Chinese media and practices [31-34].

One can argue that while the desire of China to replace or overtake the US as the World superpower is not only of China but also other 'sick nations' of western impositions, the issue of political-media values exportation, affection and integration seems to be a very slow pace with no clear strategy and singled out model despite of the revelations that both China and developing countries have favorable commonalities for harmonization in pushing for their own model.

While China's efforts for the new global media and journalism order seems to be the 'Talk of China', I argue that there should be new approach of joining and mobilizing other developing countries' media contra flows to challenge the existing dominant players [35-38].

However; the question remains, with the political and ideological incompatibility and the existence of diverse traditional media and journalism models among emerging powers and the rest of the developing countries including the emerging powerful BRICS how will this be achieved?

Perhaps this could be the reason for China to launch its own Soft Power and pushing for its domestic media and journalistic practices globally to give new approach on how stories are covered and told? But how will China manage to globalize these values alone without employing multilateral approach with other 'sick nations' of the western values but already caught in the trap of the dominant American-Liberal politics and journalism despite of the irritations?

\section{References}

1. Gagliardone I, Repnikova M, Stremlau N (2014) China in Africa: a New Approach to Media Development? - Report based on the outcome of the workshop organized by the Programme in Comparative Media Law and Policy (PCMLP) at the University of Oxford and the Stanhope Centre for Communications Policy Research.

2. Ward SJA (2008) Global Journalism Ethics: Widening the Conceptual Base Global Media Journal Canadian Edition 1: 137-149.

3. Padmanabhan N (2011) History of Journalism - Document prepared for Complementary Course offered by University of Calicut, School of Distance Education, India

4. Chalaby KJ (1996) Journalism as an Anglo-American Invention: A Comparison of the Development of French and Anglo-American Journaism 1930s - 1920s. European Journal of Communication 11: 303-326.

5. Caminit K (2014) Global Flows: Media, Culture and Globalization, Journal 4201 
Citation: Basebya KA (2018) With the Faltering Liberal Journalism Model; Is China Set to Lead Emmerging Powers in Shaping New Global Journalism?. J Mass Communicat Journalism 8: 367. doi: 10.4172/2165-7912.1000367

Page 8 of 8

6. Matos C (2012) Globalization and the Mass Media in: Encyclopedia of Globalization - Oxford: Wiley - Blackwell.

7. Reagan T, Schreffler S (2005) Higher education language policy and the challenge of linguistic imperialism: A Turkish case study. In: Lin AMY, Martin PW editors. Decolonisation, globalization: Language-in-education policy and practice Buffalo, NY: Multilingual Matters, pp: 115-130.

8. Wasserman H, de Beer ASC (2009) Towards de-westernizing journalism studies. In: Wahl-Jorgensen K, Hanitzsch T editors. The Handbook of Journalism Studies. New York: Routledge. pp: 428-438.

9. Breit R, Obijiofor L, Fitzgerald R (2013) Internationalization as DeWesternization of Curriculum: The Case of Journalism at an Austrian University - Journal of Studies in International Education 17: 119-1335.

10. Hafez K (2009) Global Journalism for Global Governance? Theoretical Visions, Practical Constraints" - Paper presented at the Media Seminar on International Reporting at the School of Communication and Design, Kalmar University, Sweden - March 19 - 20, 2009.

11. Weissmann M (2015) Chinese Foreign Policy in a Global Perspective: A Responsible Reformer 'Striving for Achiement'. Journal of Communication Research 1.

12. Lee (2004) The Conception of Chinese Journalists: Ideological Convergence and Contestation. Working papers in English and Communication 6-107-126.

13. Moyo (2009) Dead Aid: Why Aid is Not Working and How There is Another Way for Africa

14. Ehrenfeld D (2014) Foreign Aid Effectiveness, Political Rights and Bilateral Distribution. The Journal of Humanitarian Assistance-Field Experience and Current Research on Humanitarian Action and Policy.

15. Barder (2005) What Sort of Conditions Should There Be on Aid?

16. Ojo T (2012) Post-New World Information and Communication Debate: Image of Africa in the Western Media.

17. Hu Z, Ji D (2013) Retrospection, Prospection and the Pursuit of an Integrated Approach for China's Communication and Journalism Studies. Javnost- The Public 20: 5 .

18. Hu Z, Ji D (2012) Ambiguities in Communicating with the World: the 'Going Out' Policy of China's Media and Its Multilayered Contexts. Chinese Journal of Communication 5: 32-37.

19. Zhao Y (2014) Communication, Crisis, and Global Power shifts: An Introduction. International Journal of Communication 8.

20. Wang (2008) Public Diplomacy and the Rise of Chinese Soft Power. Sage Publications 616: 257-273.

21. Yang V (2015) How Chinese Media is Going Global.

22. Wang X (2012) Thorns in African Dream-1.

23. Wang $X(2012)$ Thorns in African Dream-2.
24. Jiang F, Li S, Ronning H, Tjonneland E (2016) The Voice of China in Africa: Media Communication Technologies and Image Building. Chinese journal of Communication 9: 1-7.

25. Patrick SM, Thaler FF (2010) China, the United States, and Global Governance: Shift Foundation of World Order - Workshop in Beijing, China Sponsored by the China Institutes of Contemporary International Relations (CICIR) and The Council of Foreign Relations (CFR) International Institutional and Global Governance (IIGG) program, and was made possible by the Robina Foundation.

26. Patrick S (2009) Global Governance Reform: An American View of the U.S Leadership - The Brief originally presented at a Conference on leadership and the Global governance Agenda, November $10-11,2009$, China Institutes of Contemporary International Relations (CICIR) Beijing, People's Republic of China, Co-sponsored by the Stanley Foundation together with CICIR and the Centre for International Governance Innovation.

27. Barnett S (2009) Journalism, Democracy and the Public Interest: rethinking Media Pluralism for the Digital Age- Working paper, Reuters Institute for the Study of Journalism, University of Oxford.

28. Basebya A.K (2014) "When Authoritarianism Encounters Faltering Democracy: Challenges and Strategies in China's Economic Relations with Zambia and Tanzania.

29. Benedict $R$ (2017) In the Name of Confucius: How China is Invading Western Universities with Communist Propaganda

30. Carrissimo (2017) White House Blocks CNN, BBC, New York Times, LA Times from Media Briefing - News.

31. Puddington A, Roylance T (2016) Anxious Dictators, Wavering Democracies: Global Freedom under Pressure - Freedom in the World 2016, Freedom House.

32. Henderson (2017) Donald Trump Skips White House Correspondents' Dinner to Hold a Pennsylvania 100 Day Rally- News article written and published on $28^{\text {th }}$ April, 2017 to the Telegraph Newspaper's.

33. Lai C (2016) President Xi Jinping Urges China's Journalists to conform to the Communist Party. News article written and published to the Hong Kong Free Press website on $8^{\text {th }}$ November, 2016.

34. Li K, Sparks C (2016) Chinese Newspapers and Investigative Reporting in the New Media Age. Journal of Journalism Studies 19: 415-431.

35. Lyons KF (2014) Media Globalization and its Effect upon International Communities: Seeking a Communication Theory Perspective. Global Media Journal.

36. Montinola (2007) When Does Aid Conditionality Works?

37. Shreffler MJ (2005) Verspucci Rediscovers America: The pictorial Rhetoric of Canibalism in Reality Modern Culture. Weily Online Library.

38. Tong W (2015) A Comparative Analysis of Chinese, Western and African Media Discourse in the Representation of China's Expansion of Economic Engagements in Africa LSE. 